\title{
PERBEDAAN KEJADIAN BATUK PILEK PADA BAYI USIA 7-12 BULAN DENGAN RIWAYAT PEMBERIAN ASI EKSKLUSIF DAN TIDAK ASI EKSKLUSIF
}

\author{
Latifatul Khoir Hidayati, Adriyan Pramono*)
}

Program Studi Ilmu Gizi Fakultas Kedokteran Universitas Diponegoro

J1.Dr.Sutomo No.18, Semarang, Telp (024) 8453708, Email : gizifk@ undip.ac.id

\begin{abstract}
Background : Cough and runny nose is a symptoms in upper respiratory tract that often presented in children at 712 months. Cough and runny nose is a major cause of morbidity in children younger than 5 years of age in developed countries. Symptoms of URTI such as cough, runny nose, sneezing and fever. Exclusive breastfeeding for 6 months without other companion of food or drink can be prevent the incidence of cough and runny nose because breastmilk contains some nutrients that can improved immunity in children.

Objective : To analyzed difference in the incidence of cough and runny nose in infants at the age of 7-12 months with a history of exclusive breastfeeding compared non-exclusive breastfeeding.

Method : This prospective cohort study was measured during February until April 2014 with visited to house and asked incidence of cough and runny nose every 2 weeks. Subjects were taken by purposive sampling was conducted on 60 infants at the age of 7-12 months, 22 exclusive breastfeeding infants and 38 non-exclusive breastfeeding infants. Categories of cough runny nose that studied were the episodes and duration of sick. Breastfeeding and confounding variables was obtained by interview using the closed questions.

Result : $91 \%$ in exclusive breastfeeding infants and 100\% in non-exclusive breastfeeding infants suffered of cough and runny nose for 2 months study. Compared with non-brestfed infants, incidence of cough and runny nose in exclusive breastfed infants was lower. The number of episodes and duration of cough and runny nose in subjects with a history of exclusive breastfeeding were affected by exposure to firewood smoke, mosquito coils smoke, cigarettes smoke in a row were 1 times and 2 days, 1 time and 3 days, 1 times and 3 days while in subjects with a history of non-exclusive breastfeeding were 2 times and 5 days, 3 times and 9 days, 5 times and 14 days.There was a significant differences of the episodes and duration of cough and runny nose in infants at the age of 7-12 months with a history of exclusive breastfeeding compared non-exclusive breastfeeding $(p<0,005)$.

Conclusion : Exclusive breastfeeding was protected against cough and runny nose and was associated with a reduction of respiratory morbidity in infants.
\end{abstract}

Keywords: URTI, Exclusive breastfeeding, morbidity, firewood, mosquito and cigarette smoke

\section{ABSTRAK}

Latar Belakang : Batuk pilek merupakan gejala infeksi pada saluran pernafasan atas yang sering terjadi pada anak usia 7-12 bulan. Batuk pilek menjadi penyebab utama morbiditas anak usia di bawah 5 tahun di negara berkembang. Pemberian ASI Eksklusif selama 6 bulan tanpa makanan/ minuman pendamping apapun dapat mencegah kejadian batuk pilek karena ASI mengandung beberapa zat gizi yang dapat meningkatkan kekebalan tubuh pada anak.

Tujuan : Mengetahui perbedaan kejadian batuk pilek pada bayi usia 7-12 dengan riwayat pemberian ASI Eksklusif dan tidak ASI Eksklusif

Metode : Penelitian ini menggunakan metode observasi dengan pendekatan kohort prospektif, dilakukan selama periode Februari hingga April 2014 dengan kunjungan ke rumah dan menanyakan kejadian batuk pilek setiap 2 minggu. Subjek diambil dengan cara purposive sampling sebanyak 60 bayi berusia 7-12 bulan, 22 subjek dengan riwayat pemberian ASI Eksklusif dan 38 tidak ASI Eksklusif. Kategori batuk pilek yang diteliti adalah jumlah episode dan lama hari sakit. Pemberian ASI dan variabel perancu yang mempengaruhi batuk pilek diperoleh dengan wawancara melalui pertanyaan tertutup.

Hasil : Sembilan puluh satu persen subjek dengan riwayat pemberian ASI Eksklusif dan 100\% subjek dengan riwayat tidak diberi ASI Eksklusif menderita batuk pilek dalam 2 bulan penelitian. Jumlah episode dan lama hari batuk pilek pada subjek dengan riwayat pemberian ASI Eksklusif yang terkena paparan asap kayu bakar, asap obat nyamuk bakar, asap rokok berturut-turut adalah 1 kali dan 2 hari, 1 kali dan 3 hari, 1 kali dan 3 hari sedangkan pada subjek dengan riwayat tidak diberi ASI Eksklusif adalah 2 kali dan 5 hari, 3 kali dan 9 hari, 5 kali dan 14 hari. Dibandingkan dengan bayi dengan riwayat tidak diberi ASI Eksklusif, kejadian batuk pilek pada bayi yang diberi ASI Eksklusif lebih rendah. Terdapat perbedaan jumlah episode dan lama hari sakit batuk pilek pada bayi usia 7-12 bulan dengan riwayat pemberian ASI Eksklusif dan tidak ASI Eksklusif ( $p<0,005$ ).

Simpulan : Pemberian ASI Eksklusif dapat melindungi kejadian batuk pilek dan berhubungan dengan penurunan morbiditas ISPA pada bayi.

Kata Kunci: ISPA, ASI Eksklusif, morbiditas, asap kayu bakar, obat nyamuk bakar dan rokok 


\section{PENDAHULUAN}

Batuk dan pilek merupakan gejala Infeksi Saluran Pernafasan Atas (ISPA) pada anak usia di bawah 5 tahun. Batuk secara refleks dapat menjadi faktor protektif menjaga saluran pernafasan dari obstruksi zat berbahaya yang masuk ke dalam tubuh. Hidung ditutupi oleh jaringan halus yang disebut mukosa dan menghasilkan lendir untuk melindungi hidung. Apabila jaringan ini teriritasi maka akan membengkak dan menghasilkan banyak lendir yang menyumbat hidung. Di Spanyol, data pada tahun 2007 menunjukkan bahwa dari semua kasus penyakit infeksi di Rumah Sakit, $>50 \%$ merupakan pasien balita dengan ISPA. . $2,3,4$

Sebagian besar batuk pilek pada bayi disebabkan oleh virus RSV (Respiratory Syncytial Virus) yang bersifat self limited. Self limited disease merupakan suatu penyakit yang bisa sembuh sendiri tanpa pengobatan tertentu dan lebih cepat sembuh daripada yang disebabkan oleh bakteri. Jalan masuknya virus ke dalam tubuh adalah melalui partikel udara (droplet), lalu masuk ke hidung, menempel di permukaan dinding sel epitel, masuk ke bronkus, lalu ke traktus respiratorius (saluran pernafasan) sehingga timbul gangguan saluran pernafasan. Virus juga dapat menyebar ketika status imun anak menurun dan kontak langsung dengan penderita. Risiko batuk pilek pada anak dipengaruhi oleh beberapa hal, diantaranya adalah status gizi malnutrisi, berat badan lahir rendah, paparan asap rokok, riwayat tidak diberi ASI Eksklusif, status imun rendah, paparan asap kayu bakar untuk memasak, paparan obat nyamuk bakar dan daerah tempat tinggal (pedesaan/ kota). 5, 6,7

Air Susu Ibu (ASI) diproduksi oleh alveoli yang merupakan bagian hulu pembuluh kecil air susu pada payudara ibu. Saluran air susu dan alveoli dipersiapkan untuk memproduksi air susu. ASI menjadi makanan paling cocok untuk bayi karena mempunyai zat gizi lebih banyak daripada susu formula. ${ }^{8}$ ASI Eksklusif merupakan ASI yang diberikan pada bayi selama 6 bulan tanpa makanan/ minuman pendamping apapun kecuali obat dan vitamin.

Pemberian ASI Eksklusif ini telah disarankan oleh WHO pada tahun 2001 karena mencegah risiko penularan batuk pilek pada anak di negara berkembang dan industri. ${ }^{2,8}$ Bukti terbaru dalam penelitian kohort di Inggris tahun 2010, pemberian ASI terutama ASI Eksklusif dapat menurunkan jumlah rawat inap karena ISPA sebesar 27\% setiap bulannya. Salah satu komposisi ASI adalah kolostrum yang keluar pertama kali setelah melahirkan. Kolostrum mengandung beberapa antibodi. ${ }^{9}$ Antibodi terbanyak yang terkandung dalam ASI adalah Secretory IgA (SIgA) yang aktif mendukung sistem kekebalan tubuh anak. Antibodi pada payudara ibu untuk kekebalan terhadap penyakit saluran pernafasan disebut Bronchus Associated Immunocompetent Lymphoid Tissue (BALT).

Beberapa bukti penelitian menyebutkan bahwa ASI Eksklusif sangat positif mendukung kesehatan dan menghemat biaya. Menurut penelitian pada tahun 2007, meskipun tingkat menyusui secara eksklusif di Inggris masih rendah, namun kurang dari $1 \%$ perempuan memberikan ASI Eksklusif pada bayinya. ${ }^{9,10}$ Di Afrika, Asia, Amerika Latin dan Karibia, hanya $47-57 \%$ bayi yang disusui kurang dari 2 bulan dan $25-31 \%$ bayi yang disusui selama 2-5 bulan. ${ }^{10}$ Menurut Profil Kesehatan Indonesia pada tahun 2012, cakupan pemberian ASI Eksklusif di Indonesia sebesar 48,6\%. ${ }^{11}$ Sedangkan, menurut Profil Kesehatan Provinsi Jawa Tengah (2012), cakupan pemberian ASI Eksklusif pada tahun 2012 terjadi penurunan dibandingkan tahun 2011 yaitu dari 45,18\% menjadi 25,6\%. Cakupan tertinggi di Kota Surakarta sebesar $46,1 \%$ dan yang terendah di Kabupaten Brebes sebesar 2,8\%.12 Tujuan dari penelitian ini adalah untuk mengetahui perbedaan kejadian batuk pilek pada bayi usia 7-12 bulan dengan riwayat pemberian ASI Eksklusif dan tidak ASI Eksklusif.

\section{METODE PENELITIAN}

Penelitian ini dilaksanakan di wilayah Kelurahan Penggaron Kidul Kota Semarang pada bulan Februari sampai April 2014. Jenis penelitian ini adalah penelitian observasional dengan pendekatan kohort prospektif selama 2 bulan.

Populasi terjangkau dalam penelitian ini adalah semua bayi yang berusia 7-12 bulan di Kelurahan Penggaron Kidul. Pemilihan subjek menggunakan metode purposive sampling dengan kriteria tinggal di wilayah penelitian sampai jumlah subjek terpenuhi yaitu 60 subjek. Sebanyak 22 subjek dengan riwayat pemberian ASI Eksklusif dan 38 subjek tidak diberi ASI Eksklusif. Responden adalah ibu atau pengasuh subjek.

Variabel yang diteliti dalam penelitian ini adalah variabel riwayat pemberian ASI Eksklusif dan tidak ASI Eksklusif sebagai variabel bebas sedangkan variabel kejadian batuk pilek sebagai variabel tergantung. Variabel riwayat pemberian ASI diperoleh melalui wawancara dengan pertanyaan tertutup. Subjek dikatakan menderita batuk pilek apabila lebih dari 1 hari mengalami batuk pilek. Kategori kejadian batuk pilek yang 
diteliti adalah jumlah episode dan lama hari sakit. Data tersebut diperoleh dengan menanyakan kejadian batuk pilek bayi pada responden melalui kunjungan ke rumah setiap 2 minggu sekali. Jumlah episode adalah frekuensi terjadinya batuk pilek selama 2 bulan. Episode baru batuk pilek dihitung apabila terjadi lagi setelah 2 hari tidak menderita. Lama hari sakit adalah jumlah hari menderita batuk pilek selama 2 bulan. ${ }^{13}$

Variabel perancu dalam penelitian ini adalah paparan asap kayu bakar untuk memasak, paparan asap obat nyamuk bakar dan paparan asap rokok anggota keluarga di dalam rumah. Frekuensi pemakaian kayu bakar lebih dari satu kali dalam sehari. Digunakan untuk memasak air, memasak nasi serta sayur/ lauk pada pagi hari dan memanaskan setiap waktu makan. Frekuensi pemakaian obat nyamuk bakar lebih dari satu kali sehari dan mulai digunakan sejak sore sampai menjelang pagi hari. Frekuensi merokok lebih dari satu batang setiap merokok per harinya dan dilakukan di dalam rumah. Variabel ini diambil karena merupakan polusi udara di dalam ruangan yang menyebabkan kejadian batuk pilek. ${ }^{14}$ Analisis data yang dilakukan meliputi analisis univariat dan bivariat. Pada penelitian ini, diketahui data kejadian batuk pilek dan riwayat pemberian ASI berdistribusi tidak normal sehingga dianalisis menggunakan uji beda Mann-Whitney.

\section{HASIL PENELITIAN \\ Karakteristik Reponden}

Data karakteristik responden yang diteliti adalah status pekerjaan ibu bayi. Data distribusi frekuensi dapat dilihat pada tabel 1 di bawah ini:

Tabel 1. Karakteristik Riwayat Pemberian ASI pada Ibu Bekerja dan Tidak

\begin{tabular}{lcc}
\hline \multicolumn{1}{c}{ Variabel } & ASI Eksklusif & Tidak ASI Eksklusif \\
\cline { 2 - 3 } & Frekuensi (\%) & Frekuensi (\%) \\
\hline Status Pekerjaan & & $20(80 \%)$ \\
\hline Ibu bekerja & $5(20 \%)$ & $18(51,4 \%)$ \\
Ibu tidak bekerja & $17(48,6 \%)$ & $\mathbf{3 8}(\mathbf{6 3 , 3 \% )}$ \\
\hline Total & $\mathbf{2 2 ( 3 6 , 7 \% )}$ & \\
\hline
\end{tabular}

Pada tabel 1, tampak bahwa ibu yang bekerja pada bayi dengan riwayat tidak diberi ASI Eksklusif $(80 \%)$ lebih banyak daripada ibu pada bayi dengan riwayat pemberian ASI Eksklusif $(20 \%)$

\section{Karakteristik Subjek}

Karakteristik subjek yang diambil adalah usia dan jenis kelamin. Data distribusi frekuensi dapat dilihat pada tabel 2 di bawah ini.

Tabel 2. Karakteristik subjek berdasarkan usia

\begin{tabular}{lcccccccc}
\hline \multirow{2}{*}{ Variabel } & \multicolumn{3}{c}{ ASI Eksklusif } & \multicolumn{3}{c}{ Tidak ASI Eksklusif } \\
$\mathbf{n}=\mathbf{2 2}$ & \multicolumn{3}{c}{$\mathbf{p}^{*}$} \\
\cline { 2 - 9 } & Min & Maks & Median \pm SD & Min & Maks & Median \pm SD & \\
\hline Usia (bulan) & 7 & 12 & $9,50 \pm 2,20$ & 7 & 12 & $11,50 \pm 2,06$ & 0,134 \\
\hline
\end{tabular}

*uji mann-whitney

Berdasarkan tabel 2, tidak terdapat pemberian ASI Eksklusif dan tidak diberi ASI perbedaan usia antara bayi dengan riwayat Eksklusif dimana p>0,05.

Tabel.3 Jenis kelamin subjek menurut riwayat pemberian ASI

\begin{tabular}{lccc}
\multicolumn{1}{c}{ Variabel } & ASI Eksklusif & Tidak ASI Eksklusif & \multirow{2}{*}{ p $^{*}$} \\
\cline { 2 - 3 } & Frekuensi (\%) & Frekuensi (\%) & \\
\hline Jenis kelamin & & & 0,071 \\
\hline Laki-laki & $8(25,8 \%)$ & $23(74,2 \%)$ & \\
\hline Perempuan & $14(48,3 \%)$ & $15(51,7 \%)$ & \\
\hline
\end{tabular}

*uji chi square

Tabel 3 menunjukkan bahwa jenis kelamin laki-laki (31 subjek) lebih banyak daripada perempuan (29 subjek). Tidak terdapat perbedaan jenis kelamin subjek pada kedua kelompok $(\mathrm{p}>0,05)$ 
Tabel 4. Karakteristik subjek berdasarkan paparan asap kayu bakar, asap obat nyamuk bakar dan asap rokok berdasarkan pemberian ASI

\begin{tabular}{lccc}
\hline \multicolumn{1}{c}{ Variabel } & ASI Eksklusif & Tidak ASI Eksklusif & \multirow{2}{*}{$\mathbf{p}^{*}$} \\
\cline { 2 - 3 } Paparan asap kayu bakar & Frekuensi (\%) & Frekuensi (\%) & \\
\hline Ya & $7(36,8 \%)$ & $12(63,2 \%)$ & 0,985 \\
Tidak & $15(36,6 \%)$ & $26(63,4 \%)$ & \\
\hline Paparan asap obat nyamuk bakar & & & \\
\hline Ya & $11(39,3 \%)$ & $17(60,7 \%)$ & 0,694 \\
Tidak & $11(34,4 \%)$ & $21(65,6 \%)$ & \\
\hline Paparan asap rokok & & & \\
\hline Ya & $10(27,0)$ & $27(73,0 \%)$ & 0,049 \\
Tidak & $12(52,2 \%)$ & $11(47,8 \%)$ & \\
\hline
\end{tabular}

*uji chi square

Tabel 4 menunjukkan paparan asap kayu bakar, asap obat nyamuk bakar dan asap rokok pada bayi dengan riwayat pemberian ASI Eksklusif dan tidak diberi ASI Eksklusif. Secara keseluruhan, keluarga bayi yang tidak menggunakan kayu bakar sebagai bahan bakar memasak adalah $36,6 \%$ pada bayi dengan riwayat pemberian ASI Eksklusif lebih rendah daripada keluarga bayi dengan riwayat tidak diberi ASI Eksklusif $(63,4 \%)$. Paparan asap obat nyamuk bakar lebih besar pada bayi dengan riwayat tidak
ASI Eksklusif $(60,7 \%)$ daripada bayi dengan riwayat pemberian ASI Eksklusif (39,3\%). Paparan asap rokok lebih banyak pada bayi dengan riwayat tidak diberi ASI Eksklusif (27 subjek) daripada bayi dengan riwayat pemberian ASI Eksklusif (10 subjek). Analisis bivariat menunjukkan bahwa terdapat perbedaan yang signifikan paparan asap rokok pada kedua kelompok $(\mathrm{p}<0,05)$ sedangkan tidak terdapat perbedaan paparan asap kayu bakar dan obat nyamuk bakar antara kedua kelompok ( $>>0,05)$.

Tabel 5. Jumlah episode dan lama hari sakit batuk pilek pada subjek yang terpapar asap kayu bakar, asap obat nyamuk bakar dan asap rokok

\begin{tabular}{|c|c|c|c|c|c|c|}
\hline \multirow[b]{2}{*}{ Variabel } & \multicolumn{3}{|c|}{$\begin{array}{c}\text { ASI Eksklusif } \\
n=20\end{array}$} & \multicolumn{3}{|c|}{$\begin{array}{c}\text { Tidak ASI Eksklusif } \\
n=38\end{array}$} \\
\hline & $\begin{array}{c}\text { Jumlah } \\
\text { bayi yang } \\
\text { menderita } \\
\text { batuk pilek } \\
(\%)\end{array}$ & $\begin{array}{l}\text { Jumlah } \\
\text { Episode }\end{array}$ & $\begin{array}{c}\text { Lama } \\
\text { hari } \\
\text { sakit }\end{array}$ & $\begin{array}{c}\text { Jumlah } \\
\text { bayi yang } \\
\text { menderita } \\
\text { batuk pilek } \\
(\%)\end{array}$ & $\begin{array}{l}\text { Jumlah } \\
\text { Episode }\end{array}$ & $\begin{array}{c}\text { Lama } \\
\text { hari } \\
\text { sakit }\end{array}$ \\
\hline $\begin{array}{l}\text { Terpapar asap } \\
\text { kayu bakar }\end{array}$ & $6(85,7 \%)$ & 1 kali & 2 hari & $11(91,7 \%)$ & 2 kali & 5 hari \\
\hline $\begin{array}{l}\text { Terpapar asap } \\
\text { obat nyamuk } \\
\text { bakar }\end{array}$ & $10(90,9 \%)$ & 1 kali & 3 hari & $17(100 \%)$ & 3 kali & 9 hari \\
\hline $\begin{array}{l}\text { Terpapar asap } \\
\text { rokok }\end{array}$ & $10(100 \%)$ & 1 kali & 3 hari & $27(100 \%)$ & 5 kali & 14 hari \\
\hline
\end{tabular}

Tabel 5 menunjukkan jumlah episode dan lama hari sakit batuk pilek pada subjek yang terpapar asap kayu bakar, asap obat nyamuk bakar dan asap rokok. Sebanyak 20 bayi dengan riwayat pemberian ASI Eksklusif dan 38 bayi dengan riwayat tidak diberi ASI Eksklusif menderita batuk pilek selama 2 bulan penelitian. Pada bayi dengan riwayat tidak diberi ASI Eksklusif, episode dan lama hari sakit batuk pilek lebih tinggi daripada bayi dengan riwayat pemberian ASI Eksklusif.

Perbedaan kejadian batuk pilek pada bayi usia 7-12 bulan dengan riwayat pemberian ASI Eksklusif dan tidak ASI Eksklusif

Tabel 6. Perbedaan jumlah episode dan lama hari sakit batuk pilek pada subjek dengan riwayat pemberian ASI Eksklusif dan tidak ASI Eksklusif

\begin{tabular}{cccc}
\hline \multirow{2}{*}{ Variabel } & ASI Eksklusif & Tidak ASI Eksklusif & \multirow{2}{*}{ p $^{*}$} \\
\cline { 2 - 3 } & $\mathbf{n}=\mathbf{2 2}$ & $\mathbf{n}=\mathbf{3 8}$ & \\
\cline { 2 - 3 } & Median \pm SD & Median \pm SD & $0,000^{*}$ \\
\hline Rerata jumlah episode & $2,15 \pm 0,81$ & $6,24 \pm 1,15$ & \\
\hline
\end{tabular}




\begin{tabular}{llcc}
\hline $\begin{array}{l}\text { batuk pilek dalam 2 bulan } \\
\text { Rerata lama hari sakit } \\
\text { batuk pilek dalam 2 bulan }\end{array}$ & $5,80 \pm 3,52$ & $19,16 \pm 3,69$ & $0,000^{*}$ \\
\hline *Uji perbedaan Mann-Whitney & & &
\end{tabular}

Tabel 6 menunjukkan bahwa terdapat perbedaan yang signifikan jumlah episode dan lama hari sakit batuk pilek pada bayi dengan riwayat pemberian ASI Eksklusif dan tidak diberi ASI Eksklusif dimana $\mathrm{p}<0,05$

\section{PEMBAHASAN}

Batuk dan pilek merupakan gejala infeksi pada saluran pernafasan atas yang sering terjadi pada balita. Apabila batuk dan pilek dibiarkan akan berkembang menjadi infeksi pada saluran pernafasan bawah yang berisiko kematian pada anak. Salah satu faktor protektif kejadian batuk pilek adalah pemberian ASI Eksklusif. Selama keadaan kesehatan ibu baik, anak yang baru lahir mempunyai hak mendapatkan ASI selama 6 bulan tanpa makanan pendamping apapun. Berbagai kandungan zat gizi yang terdapat di dalam ASI dapat meningkatkan kekebalan tubuh anak sampai usia dewasa sehingga terlindungi dari ISPA. 1, 2, 8

Hasil penelitian menunjukkan, subjek yang diteliti sebanyak 60 bayi, 22 bayi dengan riwayat pemberian ASI Eksklusif dan 38 bayi tidak diberi ASI Eksklusif seperti yang disajikan pada tabel 1. Status pekerjaan ibu merupakan salah satu faktor keberhasilan pemberian ASI Eksklusif karena pendeknya waktu cuti kerja dan waktu istirahat saat bekerja. ${ }^{15}$ Sebanyak 20 ibu bekerja pada kelompok dengan riwayat tidak ASI Eksklusif. Pada kelompok ASI Eksklusif juga terdapat 5 ibu yang bekerja karena mereka memanfaatkan waktu istirahat dengan menyusui di rumah. Jumlah ibu tidak bekerja pada kedua kelompok tidak jauh berbeda karena ibu pada bayi dengan riwayat pemberian ASI Eksklusif mempunyai keinginan kuat untuk memberikan ASI. Pada ibu bayi dengan riwayat tidak diberi ASI Eksklusif memiliki beberapa balita sehingga tidak fokus dalam memberikan ASI. Sebanyak $70 \%$ pekerjaan ibu subjek adalah sebagai buruh pabrik dan waktu yang dihabiskan ibu saat bekerja lebih banyak daripada di rumah.

Pemakaian kayu bakar untuk memasak pada era modern saat ini telah berganti dengan petroleum dan kompor eletrik namun di negara berkembang masih menjadi sumber utama untuk memasak. ${ }^{14}$ Berdasar tabel 5, subjek yang menderita batuk pilek karena terpapar asap kayu bakar sebanyak 6 subjek pada bayi dengan riwayat pemberian ASI Eksklusif lebih rendah daripada bayi yang tidak diberi ASI Eksklusif yaitu 11 subjek.

Menurut WHO lebih dari 2.000 kematian balita per tahun di dunia yang berhubungan langsung dengan penggunaan kayu bakar di dalam rumah. Kematian tertinggi terjadi di negara Asia Tenggara dan sub-sahara Afrika. Hal ini karena sebagian besar kegiatan anak dilakukan di dalam rumah. ${ }^{16}$ Apabila anak terpapar asap kayu bakar dalam jangka waktu lama akan membuat intoksikasi Karbon Monoksida yang terkandung dalam asap pembakaran dan merusak epitel saluran perrnafasan. ${ }^{14}$

Wilayah Penggaron Kidul termasuk wilayah yang terletak di pinggiran kota yang masih terdapat kebun/ pepohonan rimbun dan menyebabkan sarang nyamuk. Salah satu cara untuk melindungi rumah dari nyamuk adalah penggunaan obat nyamuk dan obat nyamuk bakar lebih dipilih keluarga subjek. Sesuai dengan tabel 5, subjek yang menderita batuk pilek karena terpapar asap obat nyamuk bakar sebanyak 10 subjek pada bayi dengan riwayat pemberian ASI Eksklusif lebih rendah daripada bayi yang tidak diberi ASI Eksklusif yaitu 27 subjek. Menurut EPA (Environtmental Protection Agency), obat nyamuk bakar yang tersedia di pasaran mengandung pestisida seperti piretiroid (Pyrethrum and Permethrim) dan diklasifikasikan sebagai zat karsinogenik yang dapat menyebabkan masalah pernafasan. ${ }^{17,18}$

Asap tembakau pada rokok mengandung sekitar 4000 zat organik baik berupa gas dan partikel yang bersifat toksik serta iritatif. Penelitian terbaru menunjukkan efek merugikan dari asap rokok terhadap anak karena mereka lebih sensitif terhadap polusi lingkungan. Sebagian besar perokok pada keluarga subjek adalah kakek atau ayah subjek. Berdasarkan tabel 5, subjek yang menderita batuk pilek karena terpapar asap rokok sebesar 10 subjek pada bayi dengan riwayat pemberian ASI Eksklusif lebih rendah daripada bayi yang tidak diberi ASI Eksklusif yaitu 27 subjek. Apabila anak sering terpapar asap rokok sejak dini dalam jangka waktu yang lama maka akan meningkatkan gejala ISPA, gangguan paruparu, berisiko pneumonia, bronchitis dengan frekuensi sering dan peningkatan morbiditas ISPA. ${ }^{19,20,21,22}$ 
Selama penelitian berlangsung, sebanyak $100 \%$ subjek dengan riwayat pemberian ASI Eksklusif maupun tidak ASI Eksklusif masih diberikan ASI. Subjek yang menderita batuk pilek pada kelompok dengan riwayat pemberian ASI Eksklusif sebanyak 91\% sedangkan pada kelompok tidak ASI Eksklusif sebanyak 100\% seperti yang tersaji pada tabel 4 dan lampiran 1 . Terdapat 8\% subjek pada kelompok ASI Eksklusif yang tidak menderita batuk pilek karena ibu subjek mempunyai waktu lebih banyak dalam memberikan ASI Eksklusif dan mendapat dukungan penuh dari keluarga.

Sesuai dengan teori, anak-anak yang berusia di bawah 5 tahun akan menderita batuk pilek 5-8 kali (episode) setiap tahunnya. ${ }^{23}$ Pada tabel 5 terdapat jumlah episode dan lama hari sakit batuk pilek pada subjek selama 2 bulan yang terpapar asap kayu bakar, obat nyamuk bakar dan rokok. Jumlah episode dan lama hari batuk pilek pada subjek dengan riwayat pemberian ASI Eksklusif yang terkena paparan asap kayu bakar, asap obat nyamuk bakar, asap rokok berturut-turut adalah 1 kali dan 2 hari, 1 kali dan 3 hari, 1 kali dan 3 hari lebih rendah dibandingkan dengan subjek dengan riwayat tidak diberi ASI Eksklusif yaitu 2 kali dan 5 hari, 3 kali dan 9 hari, 5 kali dan 14 hari.

Selain dari variabel-variabel di atas, kejadian batuk pilek pada penelitian ini juga disebabkan karena Gunung Kelud meletus dimana abu vulkanik sampai di wilayah ini. Sesuai dengan penelitian di Magelang Jawa Tengah pada tahun 2013 yang menyebutkan apabila anak terkena abu vulkanik gunung berapi akan menyebabkan iritasi pada saluran pernafasan. ${ }^{24}$ Pada tabel 6 menunjukkan bahwa $\mathrm{p}<0,05$ yang berarti bahwa terdapat perbedaan yang signifikan kejadian batuk pilek pada bayi dengan riwayat pemberian ASI Eksklusif dan tidak diberi ASI Eksklusif. Menurut teori, masa inkubasi setiap episode batuk pilek adalah 1-3 hari. ${ }^{25}$

Penelitian ini menunjukkan bahwa kejadian batuk pilek pada bayi dengan riwayat pemberian ASI Eksklusif lebih rendah dibandingkan dengan bayi tidak ASI Eksklusif. Sesuai dengan penelitian di Spanyol pada tahun 2012 yang menyatakan bahwa anak yang diberi ASI Eksklusif memiliki kejadian ISPA lebih rendah daripada anak tidak ASI Eksklusif. Pernyataan ini juga didukung oleh penelitian di Bangladesh yang menyatakan bahwa pemberian ASI saja pada 6 bulan pertama kehidupan bayi dapat mengurangi risiko kematian yang disebabkan oleh pneumonia dan penyakit pernafasan. Hal ini karena anak yang diberi ASI Eksklusif dapat mengembangkan mikroflora usus yang kaya akan lactobacillus dan bifidobacteria dengan mengurangi bakteri patogenik penyebab infeksi. ASI juga mengandung banyak zat gizi terutama Seng $(Z n)$ yang berfungsi meningkatkan sistem imun dan mencegah penyakit-penyakit tertentu. ${ }^{2,26,27,28}$

\section{SIMPULAN}

Kejadian batuk pilek pada bayi dengan riwayat pemberian ASI Eksklusif lebih rendah dibandingkan dengan bayi yang tidak ASI Eksklusif. Terdapat perbedaan jumlah episode dan lama hari sakit batuk pilek selama 2 bulan antara bayi dengan riwayat pemberian ASI Eksklusif dan tidak diberi ASI Eksklusif dimana $p<0,05$.

\section{SARAN}

Pemantauan kejadian ISPA pada anak sebaiknya tidak hanya didasarkan pada gejala medis saja, melainkan juga dipantau secara rutin riwayat pemberian ASI Eksklusif.

\section{DAFTAR PUSTAKA :}

1. Kartasurya MI, Ahmed F, Subagio HW, Rahlifudin MZ, Marks GC. Zinc combined with vitamin A reduces upper respiratory tract infection morbidity in a randomised trial in preschool children in Indonesia. British Journal of Nutrition 2012; 108 : 2251-60

2. Maldonado J, Canabate F, Sempere L, Vela F, Sanchez AR, Narbona E, et al. Human milk probiotic lactobacillus fermentum CECT5716 reduces the incidence of gastrointestinal and upper respiratory tract infections in infants. JPGN 2012; 54(1): 55-61

3. Reynolds SM, Mackenzie AJ, Spina S, Page CP. The pharmacology of cough. TRENDS in Pharmacological Sciences; 2004. Vol.25 No.11

4. California Childcare Health Program. Runny nose in the child care setting. California Childcare Health Program; 2009. p. 1-2

5. Danusantoso H. Ilmu Penyakit Paru. Jakarta: Penerbit Hipokrates; 2000. p. 64.

6. Valman B. Gangguan dan Penyakit yang sering menyerang anak serta cara mengatasinya. Yogyakarta: Camar; 2006. p. 94.

7. Bezerra PGM, Britto MCA, Correia JB, Duarte MdCMB, Fonceca AM, Rose Katie, et al. Viral and atypical bacterial detection in acute respiratory infection on children under five years. Journal Pone 2011; 6(4): e18928

8. Suhardjo. Pemberian makanan pada bayi dan anak. Yogyakarta: Penerbit Kanisius (Anggota IKAPI); 2010. p. 14.

9. Fisk CM, Crozier SR, Inskip HM, Godfrey KM, Cooper C, Roberts GC, et al. Breastfeeding and 
reported morbidity during infancy: findings from the Southampton Women's Survey. Maternal and Child Nutrition; 2010. p. 61-70.

10. Lamberti LM, Fischer CL, Noiman A, Victora C, Black RE. Breastfeeding and the risk for diarrhea morbidity and mortality. BMC Public Health; 2011. p. 1-12.

11. Kementerian Kesehatan Republik Indonesia. Profil Kesehatan Indonesia 2012. Jakarta: Kementerian Kesehatan Republik Indonesia; 2013. p. 187

12. Dinas Kesehatan Provinsi. Profil Kesehatan Provinsi Jawa Tengah 2012. Semarang: Dinas Kesehatan Provinsi Jawa Tengah; 2013. p. 76

13. Prajapati B, Talsania N, K N Sonaliya. A study on prevalence of acute respiratory tract infections (ARI) in under five children in urban and rural communities of Ahmedabad District, Gujarat. National Journal of Community Medicine 2011. p. 255-259

14. Sule, Nurudeen TU. The influence of primary air pollutants on human health related risk. Journal of Environment and Earth Science. 2013. p. 2224-3216

15. Ikatan Dokter Anak Indonesia. Indonesia Menyusui. Jakarta: Badan Penerbit IDAI; 2010. p. 255-256

16. World Energy Outlook 2006. Chapter 15. France: International Energy Agency. 2006; 2006. p. 419.

17. Office of Pesticide Program. Characteristics and Regulatory Status of Spatial Insect Repellents; 2009.

18. Stahl A. The Health Effects of Pesticide Used for Mosquito Control. New York: CERI; 2002. p. 2.

19. Sumartono W. Stop merokok. Jakarta: CV Sagung Seto; 2008. p. 4.

20. Bangun, AP. Sikap Bijak bagi Perokok. Jakarta: Bentara Cipta Prima; 2008. p. 16.

21. Buchanan K. Quit smoking for chicks. Jakarta: PT. Bhuana Ilmu Populer; 2003. p. 4

22. Stern G, Latzin P, Roosli M, Fuchs O, Proietti E, Kuehni C et al. A prospective study of the impact of air pollution on respiratory symptoms and infection in infants. American Journal of Respiratory and Critical Care Medicine. 2013; Vol 187. p. 13411348

23. Al-Sharbatti S, Aljumaa L. Infant feeding patterns and risk of acute respiratory infections in Baghdad/ Iraq. Italian Journal of Public Health 2012. 10.2427/7534.

24. Fuady A. Prominent diseases among internally displaced persons after Mt Merapi eruption in Indonesia. Department of Community Medicine, Faculty of Medicine, Universitas Indonesia 2013; Vol 4:2

25. Seller, RH. Diagnosis Banding Gejala yang Lazim. Jakarta: Penerbit Buku Kedokteran; 1992. p. 80.

26. Poernomo L, Suradi R, Masoara S, Durjati S, Marnoto W. Manajemen Laktasi. Jakarta: Perkumpulan Perinatologi Indonesia; 2004. p. 3-10.

27. Holden C, MacDonald A. Nutrition and Child Health. London: Baillière Tindall; 2000. p. 18-22, 40-42, 109-112.
28. World Health Organization. Infant and young child feeding. France: WHO Press; 2009. p. 4-6, 9-12, 2224. 